\title{
Studies on Sialic Acid (Neuraminic Acid) in Cerebrospinal Fluid
}

\section{Part 4: Methodology of Determination by Diphenylamine Reaction}

By

\author{
Akira Mukai \\ From the Department of Neuropsychiatry, Tohoku University School \\ of Medicine, Sendai; Director: Prof. T. Ishibashi \\ And by \\ Tatsunori Ejima
}

Iwate Prefectural Nanko Mental Hospital, Ichinoseki

(Received for publication, April 24, 1962)

\section{INTRODUCTION}

It has been recognized that sialic acid (neuraminic acid) exists widely in the mammalian body. The substance reacts characteristically to Ehrlich's p-dimethylaminobenzaldehyde reagent, Bial's orcinol reagent and Dische's diphenylamine reagent.

Sialic acid is closely related with the brain, as the name of neuraminic acid implies, and it is the characteristic component of the brain ganglioside. ${ }^{1-7}$ ) And there are many studies on it in the brain. The first report ${ }^{8,9)}$ of sialic acid in the cerebrospinal fluid (CSF) was given out in 1955. Since then, there have been some reports about it, in which Bial's reaction has been relied upon for estimation of the acid content. Since 1957 , we ${ }^{10-16}$ ) have been engaged in studies on sialic acid in human cerebrospinal fluid. In this paper are presented the results of investigation ahout the diphenylamine reaction as a method of colorimetric determination of sialic acid in CSF.

\section{MATERIALS and EXPERIMENTS}

Materials: Samples of CSF, containing less than 3 red blood cells per cubic millimeter, were obtained by lumbar puncture from human body. The samples of CSF contained from 0.15 to $0.45 \%$ of total protein by Kafka's method. 
Experiments were made with samples of the whole CSF, the protein in CSF and the protein-free CSF. The details of the samples were as follows:

Sample 1: Whole CSF.

Sample 2: $2 \mathrm{ml}$ of whole CSF plus $0.1-0.3 \mathrm{ml}$ of saturated trichloracetic acid.

Sample 3: Protein taken out ${ }^{13}$ ) by presipitation from $10 \mathrm{ml}$ CSF. $2 \mathrm{ml}$ of redistilled water or 5 per cent trichloracetic acid solution was added to the protein and mixed.

Sample 4: Niazi-State's fraction ${ }^{17}$ (sialic acid) extracted from protein by the method described elsewhere. ${ }^{14}$

Sample 5: Protein-free CSF. $0.5 \mathrm{ml}$ of saturated trichloracetic acid was added to $10 \mathrm{ml}$ of CSF. The mixture was left standing overnight and centrifuged. The sample was the supernatant obtained thereby.

Sample 6: Concentrated protein-free CSF containing the trichloracetic acid at the rate of about 5 per cent. $10 \mathrm{ml}$ of whole CSF was dried in vacun. $2 \mathrm{ml}$ of $5 \%$ trichloracetic acid solution was added to the dried CSF. The mixture was stirred with a rod and left for 20 minutes; the protein was suspended. The tube was centrifuged. $5 \%$ trichloracetic acid solution was added to the supernatant to the proper concentration.

Sample 7: Concentrated protein-free CSF. Protein in $10 \mathrm{ml}$ of CSF was precipitated with $4.0 \mathrm{ml}$ of absolute ethanol. ${ }^{13}$ ) After centrifuging, the supernatant was dried in vacuo. Redistilled water was added to the dried protein-free CSF to the proper concentration.

Sample 8: Concentrated protein-free CSF, containing trichloracetic acid at the rate of 5 per cent. Protein in $10 \mathrm{ml}$ of CSF was precipitated with $40 \mathrm{ml}$ of absolute ethanol. After centrifuging, the supernatant was dried in vacwo. $5 \%$ trichloracetic acid solution was added to the dried protein-free CSF to the proper concentration.

Sample 9: Concentrated CSF containing trichloracetic acid at the rate of 5 per cent. Whole CSF was dried in vacuo. A proper volume of 5 per cent trichloracetic acid solution was added to the dried CSF. The protein in CSF was suspended.

Sample 10: Concentrated CSF. Whole CSF was dried in vacuo. A proper volume of redistilled water was added to the dried CSF.

Procedure of the diphenylamine reaction: $2 \mathrm{ml}$ each of the samples was placed in glass-stoppered tubes. $3 \mathrm{ml}$ of diphenylamine reagent was added: the contents were mixed by shaking. The tubes were capped with glass-stoppers and heated in a vigorously boiling water bath for 30 minutes exactly. The tubes were removed and cooled with running water. The reagent blank tubes were run with each procedure and contained of $2 \mathrm{ml}$ of redistilled water or 5 per cent trichloracetic acid solution and $3 \mathrm{ml}$ of diphenylamine reagent. The reagent blanks were treated exactly like the samples at the same time. The reagent blank treated 
was decanted into a small colorimetric tube and set to 100 per cent transmission at the wave length of $530 \mathrm{~m} \mu$ on a Hitachi photo-electric spectrophotometer (TYPE EPU-2A) and the transmission of the samples was read against the reagent blank.

Reagents:

i) Diphenylamine reagent $\left.{ }^{18}\right) ; 1 \mathrm{~g}$ of diphenylamine was placed in $100 \mathrm{ml}$ graduated cylinder. $100 \mathrm{ml}$ of pure glacial acetic acid was added. Then, $2.75 \mathrm{ml}$ of concentrated sulfuric acid was added: the contents were mixed.

ii) Absolute ethanol.

iii) Saturated and 5 per cent trichloracetic acid solution.

iv) Redistilled water.

\section{RESULTS}

1) Experiment 1 (with sample 1): The blue or indigo-blue coloration appeared and the extinction value was small. As partly shown in Table $I$, the purple coloration expected appeared rarely. An extinction curve of the cases colored purple is shown in Figure 1.

2) Experiment 2 (with sample 2): The blue or indigo-blue coloration appeared more intensely than in the experiment 1. The purple coloration appeared extremely rarely.

3) Experiment 3 (with sample 3): In this experiment, the reaction produced a clear purple coloration. When the samples were concentrated to this grade, the extinction value could be estimated with confidence.

Table I. Extinction Value in Various CSF Samples by the Diphenylamine Reaction

\begin{tabular}{|c|c|c|c|c|}
\hline $\begin{array}{l}\text { Case } \\
\text { No. }\end{array}$ & Whole CSF & Supernatant $(\mathrm{I})^{k}$ & $\begin{array}{l}\text { Supernatant }(\mathrm{II}) * * \\
\text { (Concentration } \\
\text { grade) }\end{array}$ & $\begin{array}{l}\text { Whole CSF plus } \\
\text { saturated trichlor- } \\
\text { acetic acid (ml) }\end{array}$ \\
\hline 1 & .022 & .140 & $\infty \quad(10)$ & $.100(0.3)$ \\
\hline 2 & .072 & .116 & $\infty \quad(10)$ & $.105(0.3)$ \\
\hline 3 & .068 & .096 & $\infty(10) * * *$ & $.088(0.1)$ \\
\hline 4 & .090 & $.137^{* * *}$ & $\infty(10) * * *$ & $.125(0.1)$ \\
\hline 5 & .045 & .065 &.$\overline{312}$ & $.070(0.1)$ \\
\hline 6 & .046 & .065 & $.323 \quad(4)$ & $.075(0.1)$ \\
\hline 7 & $\overline{.055}^{* * * * *}$ & .129 & $\overline{308}_{1} \quad(4) * * * * *$ & $.089(0.1)$ \\
\hline 8 & .110 & .160 & $.196 \quad(2)$ & $.132(0.1)$ \\
\hline 9 & .096 & .125 & $.169 \quad(2)$ & $.120(0.1)$ \\
\hline 10 & .066 & .110 & $.296 \quad(4)$ & $.092(0.1)$ \\
\hline 11 & .092 & .096 & $.238 \quad(4)$ & $.095(0.1)$ \\
\hline
\end{tabular}

* CSF samples freed of the protein by the trichloracetic acid method.

** Protein-free CSF: The protein in the CSF dried in vacuo was removed with 5 per cent trichloracetic acid solution.

*** The coloration with a tint of purple. (The main coloration was blue).

**** The main coloration was purple. 


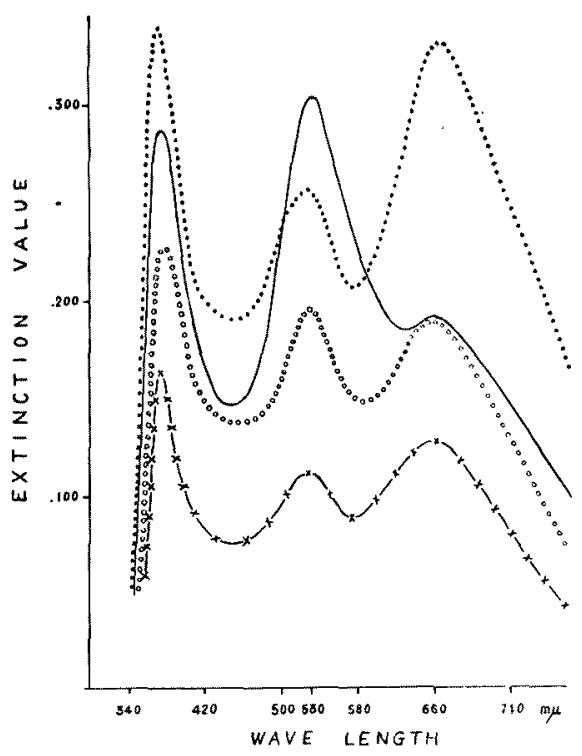

Fig. 1. Extinction curves by the diphenylamine reaction with the samples obtained from one subject at once.

- Serum Niazi-State's fraction (as a control) (Extraction into $2 \mathrm{ml}$ of 5 per cent trichloracetic acid solution from protein in $0.25 \mathrm{ml}$ serum)

$-x-x-x-$ : Whole CSF. (Experiment 1)

$\ldots \ldots \ldots$. Dried CSF sample with added 5 per cent trichloracetic acid solution.

(Experiment 9)

0 00 0 0०: Dried CSF sample dissolved in redistilled water. (Experiment I0)

4) Experiment 4 (with sample 4): The reaction produced a clear purple coloration as in the experiment with Niazi-State's fraction made from serum protein. In this experiment, the extinction value was readily estimated, when the sialic acid was extracted from the total protein in $10 \mathrm{ml}$ of CSF into 1.5 or $2 \mathrm{ml}$ of 5 per cent trichloracetic acid solution.

5) Experiment 5 (with sample 5): The reaction produced mainly a blue or indigo-blue coloration, rarely with a tinge of purple, while a purple coloration with a tint of blue appeared extremely rarely. As shown in Table I, the extinction value was larger than in experiment 1.

6) Experiment 6 (with sample 6): As partly shown in Table I, a purple coloration appeared in a small part, while in the large part was produced a blue or indigo-blue coloration. An extinction curve of the cases is shown in Figure 2.

The tests in experiments 5 and 6 were repeated 90 times. The main coloration with purple appeared 6 times and the coloration with a tint of purple 17 times, while in 67 cases, dark blue appeared with a tinge of green or indigo-blue. There was no rase showing clear purple coloration as seen in experiment 4 . 


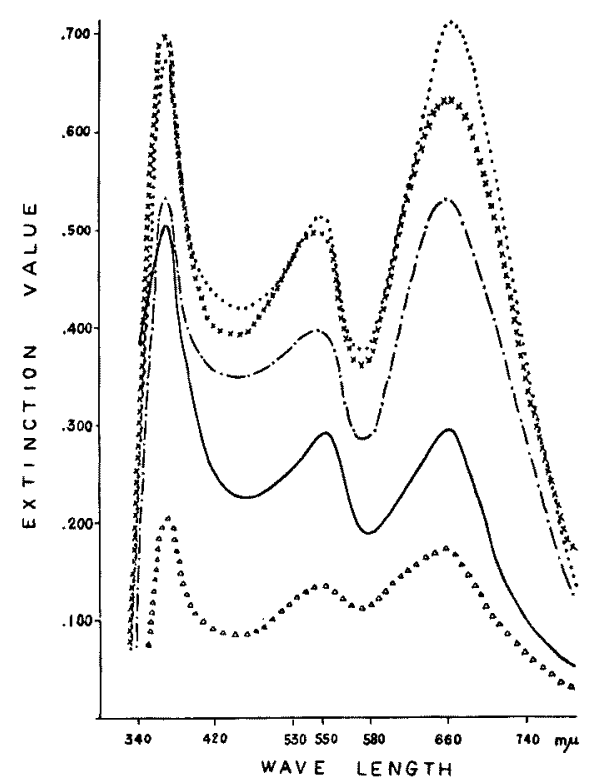

Fig. 2. Extinction curves by the diphenylamine reaction.

........ Dried CSF sample with added 5 per cent trichloracetic acid solution*. (Fxperiment 9)

$\times \times \times \times \times \times \times$ : CSF freed of protein with 5 per cent trichloracetic acid solution.* (Experiment 6)

-.....-: Dried protein-free CSF (by the ethanol method) with added 5 per cent trichloracetic acid solution.* (Concentration grade was twofold.) Experiment 8)

water. (Experiment 7)

$\Delta \Delta \Delta \Delta \Delta \Delta \Delta$ : Protein-free CSF by the trichloracetic acid method. (Experiment 5)

* These samples were obtained trom one subject at once.

7) Experiment 7 (with sample 7): Purple coloration with a tint of blue appeared in many cases. Compared with the concentrated samples freed of protein by the trichloracetic acid method, the blue or indigo-blue color appeared very faint. As shown in the extinction curve in Figure 2, the extinction value was smaller than in the experiment with samples in the same concentration prepared by the trichloracetic acid method.

8) Experiment $S$ (with sample 8): The main coloration was purple. Against our expectation, there appeared no case with the main coloration of blue or indigo-blue. But the blue coloration was more intense and the extinction value was greater than in experiment 7. The extinction curves of some cases, as shown in Figure 2, resembled the curve obtained in experiment 6 .

9) Experiment 9 (with sample 9): The main coloration was blue or indigo- 
blue with a tint of purple in most cases. The extinction curves of the reactions are shown one by one in Figures 1 and 2.

10) Experiment 10 (with sample 10): The main coloration produced was purple with a tint of blue. In a small part of the cases, it was dark purple and/or blue-indigo color. An extinction curve of the cases is shown in Figure 1.

\section{COMMENT}

In reference to the colorimetric determination adopted for estimation of sialic acid, 7 methods have been published and the most employed one is Bial's orcinol reaction. It has been recognized, ${ }^{19-27)}$ however, that diphenylamine reaction is the most suitable one, for determination of serum sialic acid. We 10,28-30) have also used it for estimating serum sialic acid. There are, however, no reports in which sialic acid in the CSF is estimated by this reaction. Therefore, we investigated the serviceability and the problems of this method. Besides, some reports ${ }^{31-36)}$ state that the free or dialyzable sialic acid exists in a larger content than the protein-bound one in CSF. We tried to test this assertion, too.

It is characteristic of sialic acid that it produces a clear purple color by diphenylamine reaction. The whole CSF samples, however, produced mostly blue or indigo-blue coloration, which was not expected for sialic acid, and the purple coloration in these experiments appeared only in a small part and the extinction value was very small. The whole CSF sample with added trichloracetic arid produced deeper blue coloration and the extinction value was higher in this case. The CSF sample freed of protein with trichloracetic acid showed the same tendency, too. Namely, the main coloration of purple appeared extremely seldom and even the coloration with a tint of purple appeared only rarely. The extinction value of these samples was larger than that of whole CSF.

On the other hand, the samples of protein extracted from CSF produced the clear purple as expected.

Also the samples of whole CSF dried in vacuo mostly showed the purple coloration. It is produced not only in the solution with added redistilled water but also in the solution with added trichloracetic acid. We cannot understand the reason. But in these experiments, most the cases produced a coloration with a tint of blue and the samples containing trichloracetic acid produced this blue coloration more intensely than the samples free of trichloracetic acid. With the samples with protein precipitated away by ethanol method, the reaction produced the same finding. As shown in Figures 1 and 2, the extinction value was far larger when the sample contained trichloracetic acid than in the case when the sample did not contain it.

Looking over Figure 1, the extinction curves indicate a difference from the curve made with Niazi-State's fraction of serum protein. In the former curves, the peak at the wave length of $660 \mathrm{~m} /$, certainly ${ }^{25,37)}$ implies the blue coloration. 
It is also suspected that more intense coloration is produced by the presence of trichloracetic acid in the system of reaction and the extinction value at $530 \mathrm{~m} \mu$, becomes larger by the same condition. With Niazi-State's fraction, the peak at $530 \mathrm{~m} \mu$, becomes conspicuous owing to the low peak at $660 \mathrm{~m} \mu$. It may be that sialic acid is much more hydrolyzed by heating for 15 minutes than the interfering substances, as indicated in many reports, ${ }^{38-41)}$ for sialic acid is bound to the end of protein. The result of following experiment demonstrates it. Namely, in the case the extraction and the diphenylamine reaction were performed at the same time by Ayala's method, ${ }^{19}$ ) the longer the heating time, the more intense the blue coloration and the larger the extinction value at $650 \mathrm{~m} \mu$.

Then, we must notice the upper three curves obtained with samples obtained from one subject at the same time, in Figure 2. There is a very small difference between the two curves made from the results of experiments 6 and 9 . It looks as if we must support the opinion that the large part of the sialic acid in CSF exists in the free form. But we hold a different view. We think it is a matter of course that the dried CSF sample with added 5 per cent trichloracetic acid solution should show the largest extinction value. But the difference is too large between the extinction value obtained from the sample freed of protein by addition of the trichloracetic acid to the dried CSF (experiment 6) and that obtained from dried CSF freed of protein by ethanol method and dissolved in the 5 per cent trichloracetic acid solution (experiment 8). If this difference is owing to the presence of mucoprotein, which is precipitated more by ethanol than by trichloracetic acid, we cannot interpret ${ }^{12}$ ) the difference between the two curves made from the samples of whole CSF and protein-free CSF.

As a whole, it is difficult to say that the large part of the sialic acid in CSF is in free form, though there is a possibility that some free sialic acid does exist in the CSF.

What we are sure at present is that there are no reliable methods for determination of the sialic acid content in CSF except the protein-bound portion. We think it is necessary to investigate the increasing blue coloration and the higher extinction value at $660 \mathrm{~m} \mu$ due to trichloracetic acid, in diphenylamine reaction of CSF samples. That is to say, it is necessary to study the method to diminish the interfering non-characteristic reaction. We think some sacrifice of sensitivity may be unavoidable for this purpose.

By the way, though the extinction value tends to rise with after the diphenylamine reaction, the degree of rise is slight. Therefore, it is recognized that diphenylamine reaction leads to stabler results than the direct Ehrlich reaction $^{13)}$ or Bial's reaction. ${ }^{12}$

\section{SUMMARY}

We examined the diphenylamine reaction for determination of sialic acid in 
various samples of the human cerebrospinal fluid. It is recognized that the reaction is an unsatisfactory method for this purpose, except in estimating the acid content in cerebrospinal fluid protein or Niazi-State's fraction. In the cases trichloracetic acid is present in the samples or the reaction system, the blue or indigo-blue coloration tends to intensify, even when the main coloration is purple, and the extinction value is heightened in its presence, not only at $530 \mathrm{~m} \mu$, but also at $660 \mathrm{~m} \mu$. It is necessary to investigate this tendency furthermore.

Though there is a possibility that some free sialic acid exists in the cerebrospinal fluid, it might be denied that free sialic acid exists in a quantity several times larger than protein-bound sialic acid.

\section{References}

1) Klenk, E., Ber. ges. Physiol. exptl. Pharmakol., 1937, 96, 659.

2) Klenk, E., Z. physiol. Chem., 1939, 262, 128.

3) Klenk, E., Z. physiol. Chem., 1941, 268, 50.

4) Klenk, E., \& Langerbeins, H., Z. physiol. Chem., 1946, 270, 185.

5) Klenk, E., Z. physiol. Chem., 1942, 273, 76.

6) Blenk, E., Ber. dtsch. Chem. Ges., 1942, 75B, 1632.

7) Klenk, E., Z. physiol. Chem., 1947, 282. 84.

8) Chatagnon, C. \& Chatagnon, P., Presse méd., 1955, 1194.

9) Roboz, E., Murphy, J.B., Hess, W.C. \& Forster, F.M., Proc. Soc. Exper Biol. \& Med., $1955,89,691$.

10) Ishida, N., Mukai, A. \& Ejima, T., Psychiatr. Neutrol. (Jap.), 1958, 60, 311.

11) Mukai, A. \& Ejima, T., Tohoku J. exper. Med., 1962, 77, 120,

12) Mukai, A. \& Ejima, T., Tohoku J. exper. Med., 1962, 77, 223.

13) Mukai, A. \& Ejima, T., Tohoku J. exper. Med., 1962, 77, 128.

14) Mukai, A. \& Ejima, T., Tohoku J. exper. Med., to be published.

15) Mukai, A. \& Ejima, T., Psychiatr. Neurol. (Jap.), 1960, 62, 102.

16) Mukai, A. \& Ejima, T., Psychiatr. Neurol. (Jap.), 1961, 63, 1013.

17) Niazi, S.M. \& State, D., Cancer Research, 1948, 8, 653.

18) Dische, Z., Mikrochemie, 1930, 8, 4.

19) Ayala, W., Moore, L.V. \& Hess, E.L., J. Clin. Invest., 1951, 30, 781.

20) Werner, I. \& Odin, L., Acta Soc. Med. Upsal., 1952, 5\%, 230.

21) Saifer, A. \& Gerstenfeld, S., J. Lab. Clin. Med., 1957, 50, 17.

22) Saito, Y., Takahashi, S. \& Turumi, K., Tohoku J. exper. Med., 1955, 62, 333.

23) Coburn, A.F., Bates, R.C., Hahn, J.W. \& Murphy, P. J., Chron. Dis., 1956, 3, 140.

24) Anderson, A.F. \& MacLagen, N.F., Biochem. J., 1955, 59, 638.

25) Hess, E.L., Hahn, J.W. \& Ayala, W., Proc. Soc. Exper. Biol. \& Med., 1956, 91, 528.

26) Svennerholm, L., Biochem. J., 1956, 64, 11 p.

27) Winzler, R.J., Determination of Serum Glycoproteins, Methods of Biochemical Analysis, New York, 1955. Interscience Publishers. Vol. 2, p. 279.

28) Mukai, A., Tnhoku Ig. z. (Jap.), 1961, 64. 12.

29) Mukai, A., Ishida, N. \& Ejima, T., Psychiatr. Neurol. (Jap.), 1958, 60, 327.

30) Mukai, A., Ishida, N. \& Ejima, T., Psychiatr. Neurol. (Jap.), 1959, 61, 626.

31) Uzman, L.L. \& Rumley, M.K., Proc. Soc. Exper. Biol. \& Med., 1956, 93, 497.

32) Uzman, L.L. \& Bering, E.A., Arch. Biochem. Biophys., 1956, 60, 257.

33) Bogoch, S., Am. J. Psychiat., 1957, 114, 172.

34) Bogoch, S., A.M.A. Arch. Neurol. \& Psychiat., 1958, 80, 221. 
35) William, S.M. \& Roboz, E., Fed. Proc. 1958, 17, 335.

36) Papadopoulos, N.M., McLane, J.E., O'Doherty, D. \& Hess, W.C., J. Nerv. \& Ment. Dis., 1959, 128, 450.

37) Stacey, M., Deriuz, R.E., Teece, E.G. \& Wiggins, F.C., Nature, 1946, 157, 470.

38) Gottschalk, A., Biochem. Biophys. Acta., 1957, 23, 645.

39) Fillard, H., Z. physiol. Chem., 1957, 307, 62.

40) Südhof, H., Kellner, H., Schönenberger, M., Haupt, H. \& Claudmitz, C., Z. physiol. Chem., 1958, 309, 136.

41) Schultze, H.E., Dtsch. med. Wschr., 1958, 83, 1742. 